\title{
Quantitative detection of soybean in meat products by a TaqMan real-time PCR assay
}

\author{
Sónia Soares a , Joana S. Amaral ${ }^{\mathrm{a}, \mathrm{b}, *}$, M. Beatriz P.P. Oliveira ${ }^{\mathrm{a}}$, Isabel Mafra ${ }^{\mathrm{a}, *}$ \\ a REQUIMTE, Departamento de Ciências Químicas, Faculdade de Farmácia, Universidade do Porto, Rua de Jorge Viterbo Ferreira, 228, 4050-313 Porto, Portugal \\ b ESTiG, Instituto Politécnico de Bragança, Campus de Sta. Apolónia, 5301-857 Bragança, Portugal
}

\section{A R T I C L E I N F O}

Article history:

Received 23 July 2013

Received in revised form 25 March 2014

Accepted 7 April 2014

Available online 18 April 2014

\section{Keywords:}

Soybean detection

Adulteration

Food allergen

Meat products

Real-time PCR

\begin{abstract}
A B S T R A C T
In the present work, we propose a normalised real-time quantitative PCR assay to determine the addition of soybean to meat products. The method proved to be a powerful tool for the quantification of soybean protein (dry basis) in the range of $0.01 \%$ to $6 \%$, being successfully in-house validated. Its application was effective in the analysis of several meat products, indicating $2 \%$ of non-compliance with the food allergen labelling legislation, and some inconsistencies when comparing the declared with estimated amounts of soybean. This work highlights the importance of efficient tools to assess labelling statements of meat products, avoiding fraudulent practices.
\end{abstract} (C) 2014 Elsevier Ltd. All rights reserved.

\section{Introduction}

Meat is considered to be a premium source of protein due to its nutritional characteristics and appreciated taste and flavour, being largely consumed in most western developed countries. Because of its high demand and economic value, adulteration issues in the meat industry and retail markets have become a widespread problem during the last years, especially in what concerns ground and comminuted meat products. Animal proteins, especially those from high quality meat sources, can attain high prices in the market, thus being prone to fraudulent substitutions, either by other lower value meat species (as occurred in the recent European horse meat scandal) or by vegetable proteins (Belloque, García, Torre, \& Marina, 2002; Fajardo et al., 2008a, 2008b; Soares, Amaral, Mafra, \& Oliveira, 2013). Although the use of vegetable proteins as meat extenders is currently a frequent practice in the meat industry, when not declared in the label, their addition to meat products encompasses a fraudulent practice used to lower production costs. In European Union (EU), clear legislation on food labelling has established 14 groups of allergenic food ingredients to be declared on the label of foods, from which soybean is included (Directive 2007/68/EC, 2007/68/EC; Regulation (EU) No 1169, 1169/2011). Moreover, in some countries, there are recommendations and/or regulations concerning the content of added vegetable proteins to specific meat products. For

\footnotetext{
* Corresponding authors. Tel.: + 351220428640.

E-mail addresses: jamaral@ipb.pt (J.S. Amaral), isabel.mafra@ff.up.pt (I. Mafra).
}

example, in Portugal, Frankfurt sausages are recommended to have no more than $5 \%$ of vegetable proteins as an optional ingredient (NP 724, 2006); the US regulation for meat products containing soybean protein allows a level of $3.5 \%$ of soybean flour and $2 \%$ of soybean protein isolate in sausages (Belloque et al., 2002); in Spain, there is a limit of 3\% of soybean protein (dry basis) (Castro, García, Rodríguez, Rodríguez, \& Marina, 2007) and in Brazil, a maximum of $0.04 \%$ of soybean protein is allowed to be used in some meat products such as hot-dog sausages and hamburgers (Brod \& Arisi, 2007). In these cases, there is the need to estimate added proteins to verify the compliance with label statements and regulations in force.

Soybean is among the most used sources of vegetable proteins in the meat industry owing to its interesting technological characteristics, such as emulsifier properties, gelling capability, texture improving and waterbinding capacity (Asgar, Fazilah, Huda, Bhat, \& Karim, 2010). Soybean also presents interesting nutritional and functional properties since it contains high-quality proteins with relatively well-balanced amino acid composition (Friedman \& Brandon, 2001), being its consumption associated with cholesterol reduction and decrease of menopause symptoms (Riaz, 1999). However, since soybean is also considered a potentially allergenic ingredient, its presence should be declared on the label of foodstuffs, regardless of the amount added (Directive 2007/68/EC, 2007/68/EC). Thus, sensitive and reliable quantitative methods are required to detect as estimate the presence of soybean addition in processed foods.

So far, several methods have been proposed for soybean detection and quantification, but they mainly rely on the analysis of proteins (immunological assays, electrophoretic and chromatographic methods) 
(Belloque et al., 2002; Castro et al., 2007; Castro-Rubio, García, Rodríguez, \& Marina, 2005; Koppelman, Lakemond, Vlooswijk, \& Hefle, 2004; Macedo-Silva, Shimokomaki, Vaz, Yamamoto, \& Tenuta-Filho, 2001; Poms, Klein, \& Anklam, 2004). Therefore, their use is of limited application in the cases of highly processed foods due to protein degradation (Rodríguez, García, González, Hernández, \& Martín, 2005; Saez, Sanz, \& Toldra, 2004). Lately, DNA-based methods have been increasingly used as highly sensitive and specific alternatives for food authentication and allergen detection (Costa, Mafra, Kuchta, \& Oliveira, 2012a; Costa, Mafra, \& Oliveira, 2012b, 2012c; Mafra, Ferreira, \& Oliveira, 2008a; Soares et al., 2013), taking advantage of the relative great thermal stability of DNA molecules compared to proteins. These techniques rely mainly on the use of polymerase chain reaction (PCR), either as qualitative end-point PCR or as quantitative real-time PCR assays. The use of hydrolysis TaqMan probes and amplification of short DNA fragments are favoured in quantitative real-time PCR analysis of processed foods due to matrix degradation and complexity.

Several studies have reported the use of PCR for soybean detection and quantification in processed meat products, but they generally aim at identifying the presence of genetically modified soybean (Brod \& Arisi, 2008; Dinon, Treml, Mello, \& Arisi, 2010; Taški-Ajduković et al., 2009), with only few studies being reported for the specific detection of soybean for quality, authenticity or allergen detection purposes in this type of foods (Meyer, Chardonnens, Hübner, \& Lüthy, 1996; Soares, Mafra, Amaral, \& Oliveira, 2010). Besides, to our knowledge, application of real-time PCR to quantify the amount of soybean in processed meat products has not been reported. Following our previous work based on the use of end-point PCR for soybean detection (Soares et al., 2010), we now propose a new and validated approach for the specific detection and quantification of soybean in processed meat products by means of a normalised real-time quantitative PCR assay coupled with fluorescent TaqMan probes.

\section{Materials and methods}

\subsection{Sample preparation}

A textured soybean (46\% protein, determined by Kjeldahl method) sample was purchased in a local supermarket, prepared following the commercial instructions (hydrated and microwave cooked, total moisture $78 \%$ ) and squeezed to eliminate as much water as possible. The final protein content of the hydrated textured soybean determined by Kjeldahl was $12.5 \%(\mathrm{w} / \mathrm{w})$.

Pork muscle was acquired in a local retail market and used to prepare reference binary mixtures containing $0.1 \%, 0.5 \%, 2.5 \%, 10.0 \%$ and $50.0 \%$ $(\mathrm{w} / \mathrm{w})$ of hydrated textured soybean in pork meat (corresponding to $0.0125 \%, 0.0625 \%, 0.313 \%, 1.25 \%$ and $6.25 \%(w / w)$ of dried soybean protein, respectively) to a final weight of $100 \mathrm{~g}$. Positive (100\% soybean) and negative ( $100 \%$ pork) control samples were also prepared. To validate the methodology, blind validation mixtures containing 1.0\% (2 mixtures), $5.0 \%$ and $25.0 \%(\mathrm{w} / \mathrm{w})$ of hydrated soybean in pork meat (corresponding to $0.125 \%, 0.625 \%$ and $3.125 \%$ (w/w) of dried soybean, respectively) were prepared in the same way as the reference mixtures. The binary and validation mixtures were triturated and homogenised using a blender after the addition of $15 \mathrm{~mL}$ of sterile phosphatebuffered saline solution ( $136 \mathrm{mM} \mathrm{NaCl}, 1.4 \mathrm{mM} \mathrm{KH}_{2} \mathrm{PO}_{4}, 8.09 \mathrm{mM}$ $\mathrm{Na}_{2} \mathrm{HPO}_{4} \cdot 12 \mathrm{H}_{2} \mathrm{O}$ and $2.6 \mathrm{mM} \mathrm{KCl}, \mathrm{pH} 7.2$ ) and stored at $-20{ }^{\circ} \mathrm{C}$ until analysis.

Samples of commercial processed meat products were purchased in local supermarkets and included hamburgers $(n=14)$, meatballs $(n=4)$, nuggets $(n=3)$, canned $(n=5)$ and bottled $(n=12)$ Frankfurt type sausages and raw/barbecue sausages $(n=4)$. All samples were ground, homogenised and stored at $-20{ }^{\circ} \mathrm{C}$ until analysis.

To avoid contaminations, all samples and mixtures were ground and homogenised separately in a knife mill Grindomix GM200 (Retsch,
Haan, Germany) using different knives and different blender containers, previously treated with DNA decontaminator solution.

\subsection{DNA extraction}

DNA was extracted using the Wizard method with minor modifications as described by Mafra, Silva, Moreira, Ferreira da Silva, and Oliveira (2008b). The extractions were performed in duplicate for each sample and binary mixtures. All extractions included a blank extraction for the control of reagents and contaminations during extraction procedure.

\subsection{DNA quantification and purity}

The DNA was quantified by spectrophotometry using a Shimadzu UV-1800 spectrophotometer (Shimadzu Corporation, Kyoto, Japan). The DNA concentration was determined by UV absorbance at $260 \mathrm{~nm}$ ( 1 absorbance unit corresponds to $50 \mathrm{ng} / \mu \mathrm{L}$ of $d s \mathrm{DNA}$ ). The purity of the extracts was evaluated based on the ratio of the absorbance at 260 and $280 \mathrm{~nm}$.

\subsection{Oligonucleotide primers}

The oligonucleotide primers used in this work were LE3/LE4 for qualitative PCR detection of soybean lectin gene (Table 1). For quantitative real-time PCR assays, the oligonucleotide primers and probes Lectin-F/ Lectin-R and Lectin-TMP were used for soybean lectin gene amplification, whilst EUK-F/EUK-R and S5 were used to amplify a fragment of nuclear 18S rRNA gene (Table 1). According to López-Andreo, Lugo, Garrido-Pertierra, Prieto, and Puyet (2005), the complete 18S rRNA gene from 50 selected eukaryotic organisms, incorporating mammals, birds, reptiles, amphibians, arthropods, molluscs, green plants, and fungi was used to select conserved regions to design the primers and probes for the quantitation of the total eukaryotic DNA in the samples. The oligonucleotide primers and probes were synthesised by Eurofins MWG Operon (Ebersberg, Germany).

\subsection{End-point PCR}

The PCR amplifications were carried out in $25 \mu \mathrm{L}$ total reaction volume containing $2 \mu \mathrm{L}$ of DNA (50-100 ng) extract, $15 \mathrm{mM}$ Tris- $\mathrm{HCl}$ ( $\mathrm{pH} 8.3$ ), $50 \mathrm{mM} \mathrm{KCl}, 0.5 \mu \mathrm{M}$ of each primer (LE3 and LE4) (Table 1), $0.2 \mathrm{mM}$ of each dNTP (Invitrogen, Carlsbad, CA, USA), $1.5 \mathrm{mM} \mathrm{MgCl} 2$ and $1 \mathrm{U}$ of DNA polymerase AmpliTaq Gold $\AA$ (Applied Biosystems, Branchburg, NJ, USA). The reactions were performed in a thermal cycler PTC-100 (MJ Research, Inc., Watertown, MA, USA) using the following programme: initial denaturation at $95{ }^{\circ} \mathrm{C}$ for $5 \mathrm{~min}, 35$ cycles of $30 \mathrm{~s}$ at $95{ }^{\circ} \mathrm{C}, 30 \mathrm{~s}$ at $60{ }^{\circ} \mathrm{C}$ and $30 \mathrm{~s}$ at $72{ }^{\circ} \mathrm{C}$, and a final extension at $72{ }^{\circ} \mathrm{C}$ for $5 \mathrm{~min}$. The amplified fragments were analysed by electrophoresis in a $2.0 \%$ agarose gel carried out in TAE buffer ( $40 \mathrm{mM}$ Tris-acetate, $1 \mathrm{mM}$ EDTA) for $60 \mathrm{~min}$ at $120 \mathrm{~V}$, stained with ethidium bromide $(0.4 \mu \mathrm{g} / \mathrm{mL}$ for $5 \mathrm{~min}$ ) and destained in distilled water for $30 \mathrm{~min}$. The agarose gel was visualised under UV light and a digital image was obtained using a Kodak Digital Science ${ }^{\mathrm{TM}}$ DC120 (Rochester, NY, USA). Each extract was amplified in duplicate assays.

\subsection{Real-time $P C R$}

The amplifications by real-time PCR were carried out in $20 \mu \mathrm{L}$ total reaction volume containing $2 \mu \mathrm{L}$ (50 ng) of DNA extract, $1 \times \mathrm{iQ}^{\mathrm{TM}}$ Supermix (Bio-Rad Laboratories, Hercules, CA, USA), $600 \mathrm{nM}$ and $900 \mathrm{nM}$ of each primer EUK-F/EUK-R and Lectin-F/Lectin-R, respectively, and $200 \mathrm{nM}$ and $100 \mathrm{nM}$ of each probe S5 and Lectin-TMP, respectively for eukaryotic and lectin genes (Table 1). Parallel reactions were prepared for each target sequence. The assays were performed on a fluorimetric thermal cycler iCycler iQ ${ }^{\mathrm{TM}}$ Real-time Detection System (Bio-Rad Laboratories, 
Table 1

Oligonucleotide primers and probes used in the PCR amplifications targeting the lectin and the 18S rRNA genes.

\begin{tabular}{|c|c|c|c|c|}
\hline Target gene & Primer/probe & Sequence $\left(5^{\prime}-3^{\prime}\right)$ & Amplicon (bp) & Reference \\
\hline \multirow[t]{2}{*}{ Lectin } & LE3 & GCA AAG CAA TGG CTA CTT CAA & 120 & Mafra et al. (2008b) \\
\hline & LE4 & AAG AAA CAG TTT CCG CTG AGT T & & \\
\hline \multirow[t]{3}{*}{ Lectin } & Lectin-F & TCC ACC CCC ATC CAC ATT T & 81 & ISO 21570 (2005) \\
\hline & Lectin-R & GGC ATA GAA GGT GAA GTT GAA GGA & & \\
\hline & Lectin-TMP & FAM-AAC CGG TAG CGT TGC CAG CTT CG-BHQ2 & & \\
\hline \multirow[t]{3}{*}{ Nuclear 18S rRNA } & EUK-F & AGC CTG CGG CTT AAT TTG AC & 120 & López-Andreo et al. (2005) \\
\hline & EUK-R & CAA CTA AGA ACG GCC ATG CA & & \\
\hline & S5 & FAM-AGG ATT GAC AGA TTG AG-BHQ2 & & \\
\hline
\end{tabular}

Hercules, CA, USA) using the following conditions: $95^{\circ} \mathrm{C}$ for $5 \mathrm{~min}, 50 \mathrm{cy}-$ cles at $95^{\circ} \mathrm{C}$ for $30 \mathrm{~s}$ and $55^{\circ} \mathrm{C}$ for $1 \mathrm{~min}$, with collection of fluorescence signal at the end of each cycle. Data were collected and processed using the iCycler $\mathrm{iQ}^{\mathrm{TM}}$ Real-time Detection System Software version 3.1. Each unknown and blind sample was amplified in triplicate and each standard in duplicate assays. Reference mixtures for calibration curve, blind and unknown samples were further amplified in independent assays $(n=$ $7, n=4$ and $n=3$, respectively).

To develop a robust quantitative method that can be applied to processed meat products, the construction of a normalised calibration curve was proposed using the real-time PCR cycle threshold $(\mathrm{Ct})$ values from the amplification of the binary reference mixtures targeting soybean (lectin gene) and the endogenous control (eukaryotic gene). For that system, the application of $\Delta \mathrm{Ct}$ method to construct a calibration model was used by calculating:

$\Delta \mathrm{Ct}=\mathrm{Ct}_{\text {soybean }}-\mathrm{Ct}_{\text {euk }}$

where $\mathrm{Ct}_{\text {soybean }}$ and $\mathrm{Ct}_{\text {euk }}$ are the cycle thresholds for soybean and eukaryotic systems, respectively. The calibration curve was then obtained by plotting the calculated $\Delta \mathrm{Ct}$ vs. the logarithm of soybean percentage of five concentration levels.

\section{Results and discussion}

The several cases of meat adulteration broadcasted by the media in the last years have intensified consumers' concerns regarding the composition of the foods they are eating. Likewise, the need to verify the compliance of labelling with legislation and the detection of economical frauds also provided a driving force towards the development of specific and sensitive methods that allow the identification of food ingredients. Nevertheless, to fully address this need, analytical methodologies should also allow performing accurate quantitative measurements beyond the specific detection of an ingredient. In particular, quantification of target ingredients is of major importance when: (i) a certain level of adventitious contamination is allowed by legislation, such as the case of authorised genetically modified organisms in European Union, whose labelling in foods is not mandatory when in amounts $<0.9 \%$ (Commission Regulation (EC) No. 1829, 1829/2003); (ii) a maximum level of an added ingredient is established in the legislation for particular products; and (iii) there is a need to verify the veracity of labels regarding the declared quantities of used ingredients.

In the present work, we propose the development of a real-time PCR assay for accurate soybean quantification based on the use of primers and probes targeting specific fragments of the lectin gene of soybean (Mafra et al., 2008b) and the eukaryotic 18S rRNA gene, as a reference control for normalisation (López-Andreo et al., 2005). To guarantee reliable and accurate quantification by real-time PCR, the use of a reference endogenous gene that takes into account possible amplification differences due to different DNA recovery and quality/degradation among extracts is of major importance (Fajardo et al., 2008a, 2008b; López-Andreo et al., 2005; Soares et al., 2013). This control is of high importance in the analysis of processed food matrices that produce low integrity and often low purity DNA extracts, allowing to normalise the differences that might affect PCR amplification and compromise reliable quantification (Sawyer, Wood, Shanahan, Gout, \& McDowell, 2003; Soares et al., 2013). It must be referred that most reported studies so far, independently of the amplified target, are applied for detection purposes without achieving true quantification.

\subsection{Real-time PCR calibration curve and linearity}

The normalised calibration curve obtained by plotting the calculated $\Delta \mathrm{Ct}$ vs. the logarithm of soybean percentage of five concentration levels is presented in Fig. 1. Therefore, the estimation of dried soybean was determined by the equation:

Soybean $\%=10^{\frac{11.732-\Delta \mathrm{Ct}}{3.7752}}$.

This approach allows the estimation of added soybean in the range of $0.0125 \%$ to $6.25 \%$ of dried soybean protein, which can be converted to hydrated textured soybean in meat in the range of $0.1 \%$ to $50 \%$. Considering that the limit of detection (LOD) is the lowest concentration level with positive identification of the analyte at least in $95 \%$ of the times, the value of $0.0125 \%$ of dried soybean protein was considered the relative LOD of the method since all replicates (14) amplified positively. The relative limit of quantification (LOQ) achieved was equal to the LOD since it was within the linear range of the calibration curve. The equation in Fig. 1 covers a linear dynamic range of a least of 3 orders of magnitude, as suggested by the MIQE (Minimum Information for Publication of Quantitative real-time PCR Experiments) guidelines of Bustin et al. (2009), with a high correlation coefficient $\left(R^{2}=0.9986\right)$. The calculation of PCR efficiency is of major relevance to assess the performance of real-time quantitative PCR assays, being calculated from the slope of the calibration curve using the following expression:

$\operatorname{PCR}$ efficiency $(\%)=\left[10^{(-1 / \text { slope })}-1\right] \times 100$.

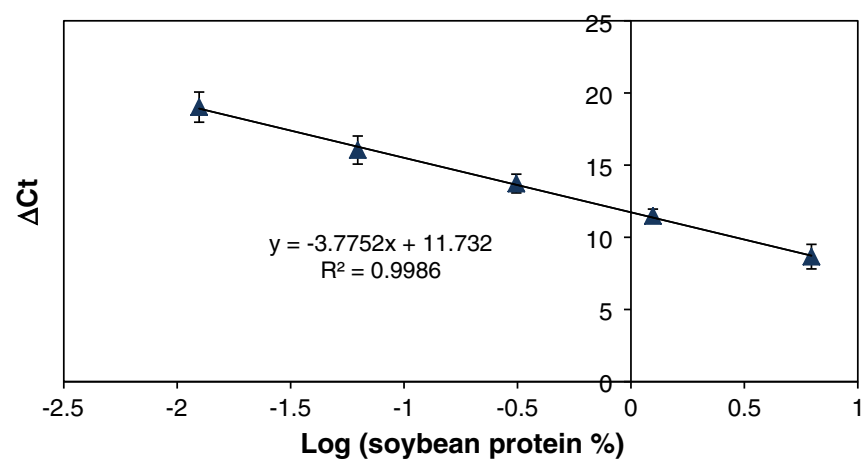

Fig. 1. Normalised calibration curve for the estimation of soybean protein in pork meat by real-time PCR with hydrolysis probes, using eukaryotic amplification as a reference gene and the $\Delta \mathrm{Ct}$ method (mean values of independent assays and the bars are the standard deviations, $n=7$ ). 
The calculated value shows that a considerably high PCR efficiency was achieved for the normalised calibration curve (84\%) and individual target amplification of soybean lectin (96.1\%) and eukaryotic (96.4\%) genes, which is particularly important for a robust and precise quantitative PCR assay (Bustin et al., 2009).

\subsection{In-house assay validation}

To validate the proposed real-time PCR methodology, binary mixtures prepared with known amounts of soybean protein in pork meat were analysed as blind samples. The respective $\mathrm{Ct}$ values for pork and soybean of amplified blind mixtures were used to calculate $\Delta \mathrm{Ct}$ and estimate the amount of soybean based on the proposed standard calibration curve presented in Fig. 1. Table 2 shows the predicted and the actual amounts of soybean in the assayed validation mixtures, which comprised two containing $0.125 \%$, and another two of $0.625 \%$ and $3.13 \%$ of soybean protein (dry basis) in meat. The $0.125 \%$ soybean protein validation mixtures (corresponding to $1 \%$ hydrated textured soybean) were analysed independently, in different days by two different analysts to obtain intra-assay variance, which refers to the precision and robustness of the assay with the same samples analysed in the same way. The low coefficients of variation, from $4.1 \%$ to $11.3 \%$ in the range of tested concentrations, evidence the high repeatability of the technique. Furthermore, the proximity between the average predicted and the actual values, as revealed by the low standard errors, demonstrates the potential of the proposed technique to accurately estimate added soybean in meat products.

\subsection{Quantitative detection of soybean in commercial processed meat products}

Results of end-point PCR and real-time quantitative PCR are resumed and compared with the labelled information regarding the addition of soybean of the 42 samples of highly processed and complex foods (Table 3). Generally, the results of qualitative PCR are in good agreement with real-time PCR data, which confirms the presence/ absence of soybean.

In the group of boiled sausages, three samples declared "vegetable protein" as an ingredient, without reference to soybean. However, soybean was detected in one (a Frankfurt type canned sausage) of these samples and at very high quantity (above the limit of quantification of $6.25 \%$ soybean protein, corresponding to $50 \%$ of hydrated soybean), which suggests that soybean was the source of labelled vegetable protein. This type of imprecise information can mislead allergic consumers to soybean that do not expect its presence as an ingredient in this particular product.

Generally, quantitative data show that when soybean protein is added to sausages it is found in a proportion from at least $1 \%$ to about $5 \%$, although in two cases of boiled sausages the levels were higher than $6 \%$. This means that most sausage samples are according to Portuguese

Table 2

Results for the validation of the real-time PCR quantitative assay.

\begin{tabular}{llllrr}
\hline \multirow{2}{*}{ Samples } & \multicolumn{2}{l}{ Soybean protein (\%, dry basis) } & SD $^{\mathrm{a}}$ & $\mathrm{CV}(\%)^{\mathrm{b}}$ & Error $^{\mathrm{c}}$ \\
\cline { 2 - 5 } & Actual & Mean predicted $^{\mathrm{d}}$ & & & \\
\hline A & 0.125 & 0.132 & 0.008 & 6.1 & 0.056 \\
$\mathrm{~B}$ & 0.125 & 0.129 & 0.015 & 11.3 & 0.034 \\
$\mathrm{C}$ & 0.625 & 0.568 & 0.023 & 4.1 & -0.091 \\
$\mathrm{D}$ & 3.13 & 3.69 & 0.33 & 8.9 & 0.180 \\
\hline
\end{tabular}

a $\mathrm{SD}$ - standard deviation.

b $\mathrm{CV}$ - coefficient of variation.

c Error $=$ (mean value - true value $) /$ true value.

${ }^{\mathrm{d}}$ Values are the means of independent assays $(n=4)$.

\section{Table 3}

Application of real-time quantitative PCR detection of soybean to commercial meat products.

\begin{tabular}{|c|c|c|c|}
\hline \multirow[t]{2}{*}{ Sample } & \multirow[t]{2}{*}{ Relevant label information } & \multicolumn{2}{|l|}{ Results } \\
\hline & & PCR (LE3/LE4) & $\begin{array}{l}\text { Real-time qPCR estimated } \\
\text { soybean protein (\%, dry basis) } \\
\text { mean } \pm \mathrm{SD}^{\mathrm{a}}\end{array}$ \\
\hline \multicolumn{4}{|c|}{ Hamburgers } \\
\hline 1 & Texturised soybean & + & $4.63 \pm 0.38$ \\
\hline 2 & & - & $\mathrm{ND}^{\mathrm{b}}$ \\
\hline 3 & & - & ND \\
\hline 4 & Rehydrated soybean & + & $4.32 \pm 0.36(34.5 \pm 2.9)^{c}$ \\
\hline 5 & protein $(30 \%)$ & - & ND \\
\hline 6 & & - & ND \\
\hline 7 & & - & ND \\
\hline 8 & Rehydrated soybean & + & $2.62 \pm 0.24(20.9 \pm 1.9)$ \\
\hline 9 & protein $(30 \%)$ & - & ND \\
\hline 10 & & - & ND \\
\hline 11 & & - & ND \\
\hline 12 & & - & ND \\
\hline 13 & Soybean protein & + & $6.00 \pm 0.17$ \\
\hline 14 & Soybean protein & + & $3.23 \pm 0.58$ \\
\hline \multicolumn{4}{|c|}{ Meatballs } \\
\hline 1 & $\begin{array}{l}\text { Rehydrated soybean } \\
\text { protein }(28 \%)\end{array}$ & + & $4.96 \pm 0.29(39.7 \pm 2.3)$ \\
\hline 2 & Rehydrated soybean & + & $2.86 \pm 0.13(22.9 \pm 1.1)$ \\
\hline 3 & protein $(30 \%)$ & - & ND \\
\hline 4 & & - & ND \\
\hline \multicolumn{4}{|l|}{ Nuggets } \\
\hline 1 & Texturised soybean & + & $2.24 \pm 0.15$ \\
\hline 2 & & - & ND \\
\hline 3 & Soybean protein & + & $5.20 \pm 0.20$ \\
\hline \multicolumn{4}{|c|}{ Boiled sausages (canned Frankfurt type) } \\
\hline 1 & Vegetable protein & + & $>6.25$ \\
\hline 2 & Soybean protein & + & $5.57 \pm 0.28$ \\
\hline 3 & Soybean protein & + & $3.82 \pm 0.39$ \\
\hline 4 & Soybean protein & + & $5.03 \pm 0.26$ \\
\hline 5 & Soybean protein & + & $1.99 \pm 0.27$ \\
\hline \multicolumn{4}{|c|}{ Boiled sausages (bottled: hot dog, bockwurst, poultry, others) } \\
\hline 1 & Vegetable protein & - & ND \\
\hline 2 & Vegetable protein & - & ND \\
\hline 3 & & - & ND \\
\hline 4 & Soybean protein & + & $>6.25$ \\
\hline 5 & Soybean protein & + & $0.89 \pm 0.08$ \\
\hline 6 & & - & ND \\
\hline 7 & & - & ND \\
\hline 8 & & - & ND \\
\hline 9 & Soybean protein & + & $1.15 \pm 0.10$ \\
\hline 10 & & - & ND \\
\hline 11 & & - & ND \\
\hline 12 & Soybean protein & + & $1.99 \pm 0.04$ \\
\hline \multicolumn{4}{|c|}{ Raw/barbecue sausages } \\
\hline 1 & Soybean protein & + & $2.69 \pm 0.30$ \\
\hline 2 & & - & ND \\
\hline 3 & & - & ND \\
\hline 4 & & - & ND \\
\hline
\end{tabular}

standards defined for the characteristics of Frankfurt type (NP 724, 2006) and raw sausages (NP 723, 2006) since both standards recommend a maximum addition of $5 \%$ of vegetable proteins. The two samples that have much higher contents (sample 1 of canned Frankfurt type sausage and sample 4 of bottled boiled sausage), above the range of quantification, suggest that they are in no compliance with the recommended standards for the referred type of products and the need for a higher upper level of calibration. The samples 2 and 4 of Frankfurt type sausages indicate also a high addition of soybean protein since the estimated 
contents were slightly above the $5 \%$ recommend value. For all the canned sausages, which have lower cost than the other types of sausages, the addition of soybean was estimated at amounts $\geq 2 \%$, suggesting that this is a frequent practice in this kind of product as a way to reduce production costs. In opposition to this, more than $50 \%$ of bottled sausage samples do not have soybean as an ingredient.

Regarding the remaining groups of samples, namely hamburgers, meatballs and nuggets, the results are all in compliance with the labelled soybean, which, when declared as an ingredient, is added within the range of $2-6 \%$ of soybean protein in more than $40 \%$ of these meat products (Table 3 ). Among them, four declared the amount of added rehydrated soybean protein, which justified the calculation of estimated soybean as rehydrated. Comparing the obtained amounts for these four samples, it can be inferred that estimated hydrated soybean protein is generally in good agreement with labelled contents. The hamburger sample 13, which did not declare the amount of added soybean material, indicated the highest soybean content in this type of products (6\%) that might suggest the fraudulent substitution of meat by soybean proteins. With respect to one meatball sample that declared $28 \%$ against the obtained $40 \%$ of hydrated soybean protein, an extra addition of soybean to decrease production costs can be suggested. However, comparison of hydrated values might be biassed due to differences in hydration levels.

\section{Conclusion}

In the present work, we propose a real-time PCR method based on the use of specific TaqMan probes that proved to be a powerful tool, highly specific, sensitive and accurate for soybean detection and quantification in the linear dynamic range of $0.01 \%$ to $6 \%$ of dry basis soybean protein. The method was successfully in-house validated, as evidenced by the low standard errors and high repeatability obtained in the analysis of blind mixtures. The applicability was effectively demonstrated in the quantitative analysis of soybean in several meat products, some declaring soybean as an ingredient and others susceptible of containing it. In general, the evaluated foods were in good agreement with legislation as most samples with no declared soybean on the label were negative for the presence of soybean DNA. However, one sample contained undeclared soybean, which indicates a $2 \%$ level of non-compliance with the food allergen labelling legislation. Additionally, most of the sausage samples also followed the recommendations of the Portuguese standard NP 724 regarding the maximum content of added soybean to this type of foods, as they generally presented $<5 \%$ soybean protein. However, the estimated soybean indicates that four sausage samples contained more than the maximum recommended amount for this type of product, being two of them were above the calibration range, which highlights the need to cover a wider quantitative range. Besides, some inconsistencies were identified comparing declared with estimated amounts of rehydrated soybean protein. In conclusion, this work highlights the importance of inspection programmes in the sector of meat products to reinforce the labelling compliance of foods, avoiding fraudulent practices and protecting the health of allergic consumers. Thus, the relevance of the proposed methodology was demonstrated as a useful tool for authentication/control, allowing the specific detection and quantification of soybean in complex foods such as the processed meat products.

\section{Acknowledgements}

This work has been supported by Fundação para a Ciência e a Tecnologia (FCT) through grant no. PEst-C/EQB/LA0006/2013 and the University of Porto "Projectos Pluridisciplinares" IJUP2011-149. S. Soares is grateful to FCT PhD grant (SFRH/BD/75091/2010) financed by POPH QREN (subsidised by FSE and MCTES).

\section{References}

Asgar, M. A., Fazilah, A., Huda, N., Bhat, R., \& Karim, A. A. (2010). Nonmeat protein alternatives as meat extenders and meat analogs. Comprehensive Reviews in Food Science and Food Safety, 9, 513-529.

Belloque, J., García, M. C., Torre, M., \& Marina, M. L. (2002). Analysis of soyabean proteins in meat products: A review. Critical Reviews in Food Science and Nutrition, 42(5), 507-532.

Brod, F. C. A., \& Arisi, A. C. M. (2007). Recombinant DNA in meat additives: Specific detection of Roundup Ready ${ }^{\mathrm{TM}}$ soybean by nested PCR. Journal of the Science of Food and Agriculture, 87, 1980-1984

Brod, F. C. A., \& Arisi, A. C. M. (2008). Quantification of Roundup Ready ${ }^{\mathrm{TM}}$ soybean in Brazilian soy-derived foods by real-time PCR. International Journal of Food Science $\mathcal{E}$ Technology, 43, 1027-1032.

Bustin, S. A., Benes, V., Garson, J. A., Hellemans, J., Huggett, J., Kubista, M., Mueller, R., Nolan, T., Pfaffl, M. W., Shipley, G. L., Vandesompele, J., \& Wittwer, C. T. (2009). The MIQE guidelines: Minimum information for publication of quantitative real-time PCR experiments. Clinical Chemistry, 55, 611-622.

Castro, F., García, M. C., Rodríguez, R., Rodríguez, J., \& Marina, M. L. (2007). Determination of soybean proteins in commercial heat-processed meat products prepared with chicken, beef or complex mixtures of meats from different species. Food Chemistry, $100,468-476$

Castro-Rubio, F. García, M. C. Rodríguez, R. \& Marina, M. L. (2005). Simple and inexpensive method for the reliable determination of additions of soybean proteins in heatprocessed meat products: An alternative to the AOAC official method. Journal of the Agricultural and Food Chemistry, 53, 220-226.

Commission Regulation (EC) No. 1829/2003 of the European Parliament and of the Council of 22 September 2003 on genetically modified food and feed. Official Journal of the European Union, L 268, 1-37.

Costa, J., Mafra, I., Kuchta, T. \& Oliveira, M. B. P. P. (2012a). Single-tube nested real-time PCR as a new highly sensitive approach to trace hazelnut. Journal of Agricultural and Food Chemistry, 60, 8103-8110.

Costa, J., Mafra, I., \& Oliveira, M. B. P. P. (2012b). Advances in vegetable oil authentication by DNA-based markers. Trends in Food Science and Technology, 26, 43-55.

Costa, J., Mafra, I., \& Oliveira, M. B. P. P. (2012c). High resolution melting analysis as a new approach to detect almond DNA encoding for Pru du 5 allergen in foods. Food Chemistry, 133, 1062-1069.

Dinon, A. Z., Treml, D., Mello, C. S., \& Arisi, A. C. M. (2010). Monitoring of GMO in Brazilian processed meat and soy-based products from 2007 to 2008. Journal of Food Composition and Analysis, 23, 226-229.

Directive 2007/68/EC of 27 November 2007 amending Annex IIIa to Directive 2000/13/EC of the European Parliament and of the Council as regards certain food ingredients. Official Journal of the European Union, L 310, 11-14.

Fajardo, V. Gonzalez, I., Martín, I., Rojas, M., Hernandéz, P. E. García, T. \& Martín, R. (2008a). Real-time PCR for detection and quantification of red deer (Cervus elaphus), fallow deer (Dama dama), and roe deer (Capreolus capreolus) in meat mixtures. Meat Science, 79, 289-298.

Fajardo, V., González, I., Martín, I., Rojas, M., Hernández, P. E., García, T., \& Martín, R. (2008b). Real-time PCR for quantitative detection of chamois (Rupicapra rupicapra) and pyrenean ibex (Capra pyrenaica) in meat mixtures. Journal of AOAC International, 91, 103-111.

Friedman, M., \& Brandon, D. L. (2001). Nutritional and health benefits of soy proteins. Journal of Agriculture and Food Chemistry, 49, 1069-1077.

ISO 21570 (2005). Foodstuffs - Methods of analysis for the detection of genetically modified organisms and derived products - Quantitative nucleic acid based methods, Switzerland. ISO: Geneva.

Koppelman, S. J., Lakemond, C. M. M., Vlooswijk, R., \& Hefle, S. L. (2004). Detection of soy proteins in processed foods: Literature overview and new experimental work. Journal of AOAC International, 87, 1398-1407.

López-Andreo, M., Lugo, L., Garrido-Pertierra, A., Prieto, M. I., \& Puyet, A. (2005). Identification and quantitation of species in complex DNA mixtures by real-time polymerase chain reaction. Analytical Biochemistry, 339, 73-82.

Macedo-Silva, A., Shimokomaki, M., Vaz, A. J., Yamamoto, Y. Y., \& Tenuta-Filho, A. (2001). Textured soy protein quantification in commercial hamburger. Journal of Food Composition and Analysis, 14, 469-478.

Mafra, I., Ferreira, I. M. P. L. V., \& Oliveira, M. B. P. P. (2008a). Food authentication by PCRbased methods. European Food Research and Technology, 227, 649-665.

Mafra, I., Silva, S. A., Moreira, E. J. M. O., Ferreira da Silva, C. S., \& Oliveira, M. B. P. P. (2008b). Comparative study of DNA extraction methods for soybean derived food products. Food Control, 19, 1183-1190.

Meyer, R., Chardonnens, F., Hübner, P., \& Lüthy, J. (1996). Polymerase chain reaction (PCR) in the quality and safety assurance of food: Detection of soya in processed meat products. Lebensmitteluntersuchung und Forschung A, 203, 339-344.

NP 723 (2006). Salsicha fresca. Definição e características. : Instituto Português da Qualidade (IPQ).

NP 724 (2006). Salsicha tipo "Frankfurt". Definição e características. : Instituto Português da Qualidade (IPQ).

Poms, R. E., Klein, C. L., \& Anklam, E. (2004). Methods for allergen analysis in food: A review. Food Additives and Contaminants, 21, 1-31.

Regulation (EU) No 1169/2011 of 25 October 2011 on the provision of food information to consumers, amending Regulations (EC) No 1924/2006 and (EC) No 1925/2006 of the European Parliament and of the Council, and repealing Commission Directive 87/250/EEC, Council Directive 90/496/EEC, Commission Directive 1999/10/EC, Directive 2000/13/EC of the European Parliament and of the Council, Commission Directives 2002/67/EC and 2008/5/EC and Commission Regulation (EC) No 608/ 2004, Official Journal of the European Union, L304, 18-63. 
Riaz, M. N. (1999). Soybeans as functional foods. Cereal Foods World, 44, 88-92.

Rodríguez, M. A., García, T., González, I., Hernández, P. E., \& Martín, R. (2005). TaqMan real-time PCR for the detection and quantitation of pork in meat mixtures. Meat Science, 70, 113-120.

Saez, R., Sanz, Y., \& Toldra, F. (2004). PCR-based fingerprinting techniques for rapid detection of animal species in meat products. Meat Science, 66, 659-665.

Sawyer, J., Wood, C., Shanahan, D., Gout, S., \& McDowell, D. (2003). Real-time PCR for quantitative meat species testing. Food Control, 14, 579-583.

Soares, S., Amaral, J. S., Mafra, I., \& Oliveira, M. B. P. P. (2013). A SYBR Green real-time PCR assay to detect and quantify pork meat in processed poultry meat products. Meat Science, 94, 115-120.
Soares, S., Mafra, I., Amaral, J. S., \& Oliveira, M. B. P. P. (2010). A PCR assay to detect trace amounts of soybean in meat sausages. International Journal of Food Science and Technology, 45, 2581-2588.

Taški-Ajduković, K., Nikolić, Z., Vujaković, M., Milošević, M., Ignjatov, M., \& Petrović, D. (2009). Detection of genetically modified organisms in processed meat products on the Serbian food market. Meat Science, 81, 230-232. 